\title{
Outline Classification of Bacterium and Staphylococcus
}

\author{
By S. T. COWAN and CONSTANCE SHAW \\ National Collection of Type Cultures, Lister Institute, Elstree, Herts
}

SUMMARY: The National Collection of Type Cultures, in its list of species maintained, uses unorthodox classifications of the genera Bacterium and Staphylococcus. For convenience in cataloguing Bacterium is divided into groups representing coliforms, plant pathogens, non-fermenting species and paracolons; to these is added a miscellaneous group of organisms of uncertain taxonomic position. These subdivisions are not intended to constitute a valid classification.

Coagulase-positive staphylococci, irrespective of pigment, form the species pyogenes; coagulase-negative strains are subdivided according to the pigment produced.

\section{BACTERIUM}

The National Collection of Type Cultures (1948) recognizes the genera Salmonella and Shigella but includes most of the other Gram-negative intestinal bacilli in the genus Bacterium, which is defined in a broad sense:

Bacterium. Gram-negative rods, usually motile by peritrichous flagella. Grow readily on simple media and most groups are active in fermenting carbohydrates. Most species do not liquefy gelatin. Widely distributed in nature.

Type species: Bacterium coli Escherich.

Within the genus five groups are recognized:

Coli-aerogenes, active fermenters of carbohydrates, usually with the production of gas; all species ferment lactose.

Erwinia, similar to coli-aerogenes but pathogenic for plants; usually ferment salicin.

Friedländer, capsulated bacilli producing mucoid colonies; usually isolated from the respiratory tract.

Non-fermenting, fail to ferment any carbohydrates; sometimes produce alkali in milk.

Paracolon, active fermenters of carbohydrates; late or no fermentation of lactose.

For ease of reference we have listed the plant pathogens as a separate group, but we agree with Dowson (1939) that these organisms should be regarded as members of the main coli-aerogenes group, with Bacterium coli as the type species. Habitat is an undesirable criterion in a systematic classification, but for convenience in preparing our list we adopted it to separate coliforms from Erwinia and the Friedländer group from aerogenes. We hesitate to abolish the Friedländer group, but we do not feel justified in giving it generic rank; further study of antigenic make-up will probably decide the matter.

The paracolon group is differentiated on the one hand from the coli-aerogenes group by the non-lactose-fermenting or late-lactose-fermenting character of the organisms, and on the other hand from Salmonella and Shigella by differences in antigenic structure. The work of Edwards, West \& Bruner (1947) has done much to show the relationship of certain paracolons (Arizona group) to the 
salmonellas. The non-fermenting group is clearly differentiated from the other groups, but it is not homogeneous. Our work with this group suggests that eventually at least two genera may be justified.

In general we agree with the view of Borman, Stuart \& Wheeler (1944) that the Gram-negative bacilli which we call Bacterium, and they call Colobactrum,

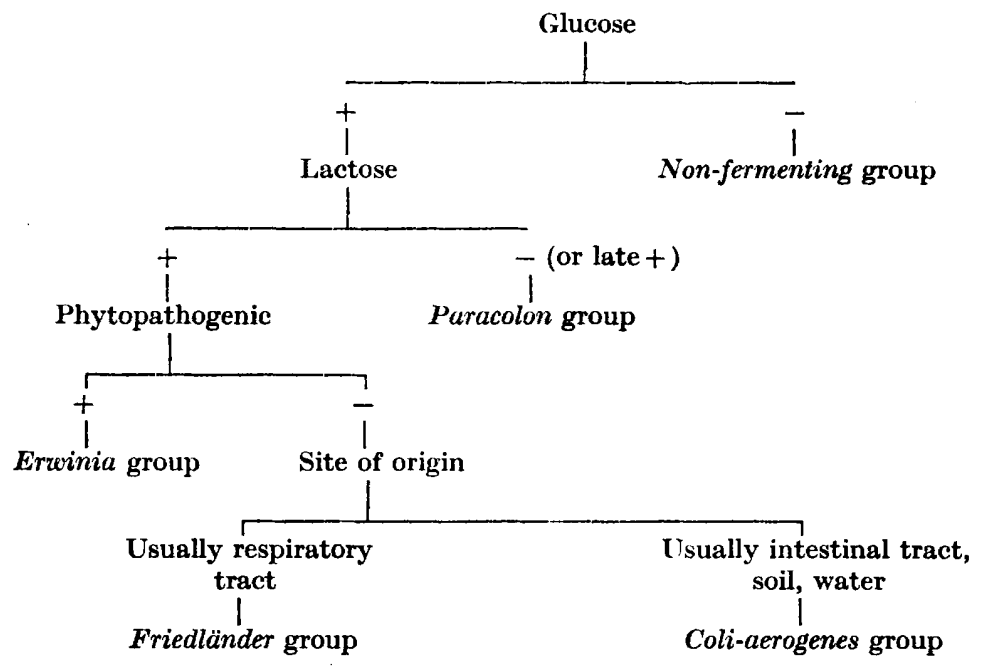

Fig. 1. Differentiation of groups within the genus Bacterium.

Paracolobactrum, Erwinia, and Proshigella, show a series of gradations which blend one into another. We differ in not yet being prepared to treat Bacterium (Enterobacteriaceae) as a family and subdivide it into genera. Like Wilson \& Miles (1946), we recognize groups within our genus Bacterium and know that some may eventually be accorded generic rank.

Finally, in the National Collection of Type Cultures List we have included a group 'Bacterium'. The word Bacterium is printed here within quotes and in our List in roman to indicate that we do not regard this group as homogeneous or the organisms in it as necessarily related to the rest of our genus Bacterium. It includes species (mostly Gram-negative rods) that have been insufficiently studied or described to justify their allocation to accepted genera. In short this group consists of organisms of uncertain taxonomic status and is merely a cataloguer's dump-heap.

\section{STAPHYLOCOCCUS}

Staphylococcus may be defined in one of two ways; the first includes all monomorphic Gram-positive cocci arranged in clusters, the second, more sharply circumscribed, is limited to the cocci that produce the enzyme coagulase. We propose to outline the points in favour of and against these definitions in turn.

Staphylococcus Ogston (1882) emend. Monomorphic, Gram-positive cocci less than $1 \mu$ in diameter, arranged in pairs in young cultures and in irregular clusters in older cultures. Grow readily on simple media. Under suitable conditions white, yellow, 
or gold colonies are produced. Some species produce characteristic enzymes and toxins. Mainly saprophytes but sometimes pathogenic to man and animals.

Type species: Staphylococcus pyogenes Rosenbach emend.

The characteristic enzymes are staphylocoagulase and fibrinolysin. The coagulase test should be standardized and carried out with human plasma (Gillespie, 1943; Williams \& Harper, 1946); we stress this because recent work suggests that different mechanisms take part in the reaction when plasma of different species are used (Smith \& Hale, 1944). A genus so defined would be acceptable to most bacteriologists; however, on grounds of pleomorphism and pigment it would exclude organisms such as Staphylococcus flavo-cyaneus (Knaysi, 1942). The chief and formidable objection to this definition is that the borderline between this genus and Micrococcus is ill-defined, because it rests on the diameter of the cocci and therefore on uniformity in size and shape. Most micrococci have cells $1 \mu$ or more in diameter and show variation in size, but cell size may vary so much under different cultural conditions that it is impossible to make a precise dividing line between the two genera.

The second definition we considered was simpler:

Staphylococcus Ogston (1882) emend. Gram-positive cocci that produce an enzyme capable of clotting human plasma.

Type species: Staphylococcus pyogenes Rosenbach emend.

Such a genus is neat and compact; it consists of organisms that are all closely related serologically, sharing a series of specific antigens (Cowan, 1939; Christie \& Keogh, 1940; Hobbs, 1948). Furthermore, most strains of this genus are susceptible to one or more of a series of staphylococcal bacteriophages (Wilson \& Atkinson, 1945). Most strains are capable of producing one or more of the recognized staphylococcal toxins, and all are regarded as potentially pathogenic (Cruickshank, 1937; Fairbrother, 1940; Miles, Williams \& ClaytonCooper, 1944).

It may be objected that the definition excludes a group of coagulasenegative, monomorphic, Gram-positive cocci that are normally accepted as staphylococci. This group would have to be placed either in a new genus created for them or in the genus Micrococcus. For our part we should not object to enlarging the genus Micrococcus to include this group and should like to have defined Staphylococcus to exclude it; but in preparing the N.C.T.C. List we had to bear in mind that it would be read by scientists of all kinds and that all must be able to recognize the species named. As a consequence our genus Staphylococcus had to conform to the first definition given above and include both coagulase-positive and coagulase-negative forms. While this definition is now generally acceptable we think that systematists, bearing in mind the importance of antigenic relationships, may ultimately adopt a definition closer to our second but with another criterion in place of coagulase, such as sensitivity to a polyvalent staphylococcal bacteriophage.

Our genus Staphylococcus, conforming to the first definition, is divided into five species, whose differentiation is shown in the second schema (Fig. 2).

Coagulase for human plasma is one of the most stable characters of staphy- 
lococci, and the primary subdivision is made on the production of this enzyme; all positive strains, irrespective of pigment, are named Staphylococcus pyogenes. Pigment production is regarded as having only secondary importance, and we do not recognize the varieties albus, aureus and citreus of the genus pyogenes. These varieties cut across the more stable characters such as antigenic structure and phage type.

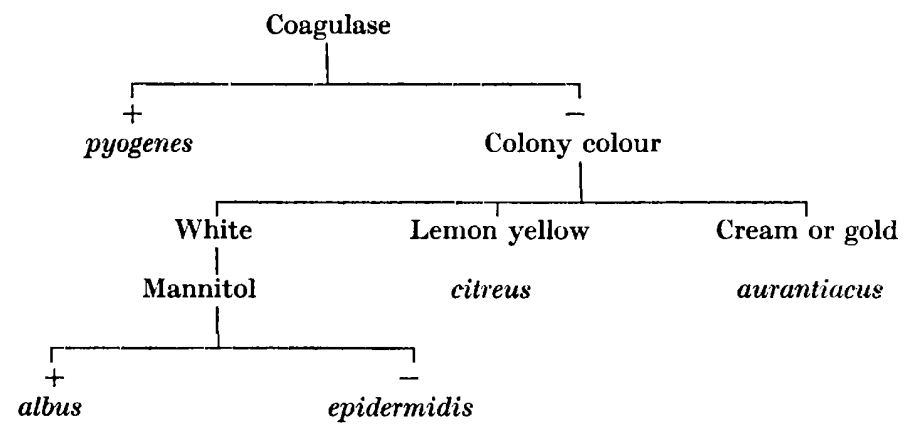

Fig. 2. Differentiation of species within the genus Staphylococcus.

In the absence of better differential characters pigmentation is of some use in the subdivision of the coagulase-negative group, and we recognize the species aurantiacus and citreus on the ground of pigment alone. White-coloured strains are divided into two species by the fermentation of mannitol; our species epidermidis agrees largely with Andrewes \& Gordon's (1907) Staphylococcus epidermidis-albus and with Cowan's (1938) Staphylococcus epidermidis; to the mannitol-fermenting strains we have given the name Staphylococcus albus, which agrees with the species so named of Bergey, Breed, Murray \& Hitchins (1939).

\section{REFERENCES}

Andrewes, F. W. \& Gordon, M. H. (1907). Report on the biological characters of the staphylococci pathogenic for man. 35th Ann. Rep. loc. Govt. Bd, Rep. med. Off. 1905-6, App. B, no. 7, p. 543.

Bergey, D. H., Breed, R. S., Murray, E. G. D. \& Hitchins, A. P. (1939). Bergey's Manual of Determinative Bacteriology, 5th ed., p. 264. London: Baillière, Tindall and Cox.

Borman, E. K., Stuart, C. A. \& Wheeler, K. M. (1944). Taxonomy of the family Enterobacteriaceae. J. Bact. 48, 351.

Christie, R. \& Keogh, E. V. (1940). Physiological and serological characteristics of staphylococci of human origin. J. Path. Bact. 51, 189.

Cowan, S. T. (1938). The classification of staphylococci by precipitation and biological reactions. J. Path. Bact. 46, 31.

Cowan, S. T. (1939). Classification of staphylococci by slide agglutination. J. Path. Bact. 48, 169.

Cruickshank, R. (1937). Staphylocoagulase. J. Path. Bact. 45, 295.

Dowson, W. J. (1939). On the systematic position and generic names of the Gramnegative bacterial plant pathogens. Z Zbl. Bakt. II Abt. 100, 177.

Edwards, P. R., West, M. G. \& Bruner, D. W. (1947). Arizona group of paracolon bacteria: a new group of bacteria pathogenic for animals and probably also for man. Bull. no. 499. Ky Agric. Exp. Sta. 
FaIrbrother, R. W. (1940). Coagulase production as a criterion for the classification of the staphylococci. J. Path. Bact. 50, 83.

Gillespie, E. H. (1943). The routine use of the coagulase test for staphylococci. Mon. Bull. Emerg. publ. Hlth Lab. Serc. $2,19$.

HoвBs, B. C. (1948). A study of the serological type differentiation of Staphylococcus pyogenes (in the Press).

KNAYSI, G. (1942). The demonstration of a nucleus in the cell of a staphylococcus. J. Bact. 43, 365.

Miles, A. A., Willitams, R. E. O. \& Clayton-Cooper, B. (1944). The carriage of Staphylococcus (pyogenes) aureus in man and its relationship to wound infection. J. Path. Bact. 56, 513.

National Collection of Type Cultures (1948). List of Species Maintained in the National Collection of Type Cultures, Med. Res. Coun. Memo. No. 21. London: H.M. Stationery Office.

Ogston, A. (1882). Micrococcus poisoning. J. Anat. Physiol. 17, 24.

Smith, W. \& HALE, J. H. (1944). The nature and mode of action of staphylococcus coagulase. Brit. J. exp. Path. 25, 101.

Williams, R. E. O. \& Harper, G. J. (1946). Determination of coagulase and alphahaemolysin production by staphylococci. Brit. J. exp. Path. 27, 72.

Wilson, G. S. \& Atrinson, J. D. (1945). Typing of staphylococei by the bacteriophage method. Lancet, i, 647 .

Wilson, G. S. \& Mrues, A. A. (1946). Topley \& Wilson's Principles of Bacteriology and Immunity, 3rd ed., p. 654. London: Arnold.

(Received 10 April 1948) 